\title{
KRAFT PULPING OF EUCALYPTUS GLOBULUS AS A PRETREATMENT FOR BIOETHANOL PRODUCTION BY SIMULTANEOUS SACCHARIFICATION AND FERMENTATION
}

\author{
MARIEL MONRROY, ${ }^{1,4}$ JOSÉ-RENÁN GARCÍA, ${ }^{2,4}$ REGIS TEIXEIRA MENDONÇA, ${ }^{1,2}$ \\ JAIME BAEZA, ${ }^{1,3}$ AND JUANITA FREER ${ }^{1,3, *}$
}

\author{
${ }^{1}$ Renewable Resources Laboratory, Biotechnology Center, Universidad de Concepción, Concepción, Chile. \\ ${ }^{2}$ Faculty of Forestry Sciences, Universidad de Concepción, Concepción, Chile. \\ ${ }^{3}$ Faculty of Chemical Sciences, Universidad de Concepción, Concepción, Chile. \\ ${ }^{4}$ Department of Chemistry, Faculty of Natural and Exact Sciences, Universidad Autónoma de Chiriquí, Panamá.
}

(Received: July 20, 2011 - Accepted: January 20, 2012)

\begin{abstract}
The kraft pulping process was evaluated in this study as a pretreatment of Eucalyptus globulus for bioethanol production. Wood chips were pretreated under different pulping conditions $\left(155^{\circ} \mathrm{C}\right.$ and $165^{\circ} \mathrm{C} ; 15$ and $20 \%$ alkali active AA, 15-60 min). A total of 12 pulps were obtained, with pulp yields ranging from 49 to $57 \%$. Glucan remained in pulps were from $77 \%$ and $90 \%$, while $50 \%$ of the hemicelluloses were solubilized. Lignin removal increased with increased severity of cooking (high active alkali charge, pretreatment time and temperature) reaching delignification over $78 \%$. The enzymatic hydrolysis of kraft pulps with cellulase presented a rapid glucan conversion rate to glucose with values over $90 \%$. Lignin, hemicellulose removal, as well as, cellulose polymerization degree showed an effect on the increment of enzymatic hydrolysis. The degree of crystallinity increased slightly between 1-5\%, having no effect on the enzymatic hydrolysis. The simultaneous saccharification and fermentation was performed (SFS) at $10 \%$ substrate consistency with a production at 30-38 g ethanol/L. The maximum amount of ethanol that could be produced from E. globulus is $258 \mathrm{~g}$ ethanol $/ \mathrm{kg}$ wood, assuming total glucose conversion into ethanol. The amounts of ethanol obtained from the different pulps varied between 168-202 $\mathrm{g}$ ethanol $/ \mathrm{kg}$ wood. The ethanol yields obtained from kraft pulps varied between 65 and $78 \%$ (wood basis). The maximum ethanol yield was $78 \%$ at $155^{\circ} \mathrm{C}, 15 \% \mathrm{AA}$ and $60 \mathrm{~min}$ reaction, while the yield was $74 \%$ at $165^{\circ} \mathrm{C}, 15 \% \mathrm{AA}$ and 30 min of reaction time. Results showed that an efficient enzymatic hydrolysis at low enzyme loads could be obtained from kraft pulps employing less severe conditions than those used to produce bleachable-grade pulps.
\end{abstract}

Keywords: kraft pulping, E. globulus, SFS and bioethanol

\section{INTRODUCTION}

Ethanol derived from lignocellulosic biomass (LCB) has long been recognized as a potential alternative for non-renewable transportation fuels ${ }^{1}$. Eucalyptus, poplar and pine are commercially important fast-growing trees. Eucalyptus provides raw material for papermaking and is widely used in the construction industries, although large amounts of wood residue, such as bark, cork residue, cross-cut ends, edgings, grinding dust and saw have not been efficiently utilized. In the long term, fast-growing eucalyptus is one of the most promising types of cellulose feedstock for ethanol production due to its high cellulose content ${ }^{2}$.

Due to LCB recalcitrance to enzymatic hydrolysis, owing to its rigid structure, the interaction between cellulose and hemicellulose plus the degree of lignification, a pretreatment process is necessary to disrupt the lignocellulosic matrix and increase its enzymatic digestibility ${ }^{3}$. The goal of the pretreatment is to alter the physical features and chemical composition. Specifically, pretreatment improves enzyme access and effectiveness by breaking the lignin seal, removing hemicellulose, and disrupting the crystalline structure of cellulose $e^{4-7}$

Various methods have been developed for pretreating LCB. These pretreatments can be classified into various categories: physical (milling and grinding), physicochemical (steam explosion/autohydrolysis, hydrothermolysis and wet oxidation), chemical (alkali, acid, oxidizing agent and organic solvents) and biological (fungi) ${ }^{4,8-12}$. Some have demonstrated effectiveness in disrupting lignin cellulose complex, while others are responsible for breaking down the highly ordered cellulose crystalline structure ${ }^{11}$.

Chemical pretreatment methods have received significant attention because they increase the accessibility to hydrolytic attack ${ }^{11}$. A wide variety of chemicals have been suggested in the literature, including sodium hydroxide, sulfur dioxide, aqueous ammonia, calcium hydroxide, calcium carbonate, phosphoric acid, alkaline hydrogen peroxide, inorganic salts with acidic properties, ammonium salts, acids (with acetic, formic, and sulfuric being the most used), organic acid anhydrides, and alcohols (methanol, ethanol or butanol) in the presence of an acid or alkaline catalyst ${ }^{12,13}$.

Chemical pretreatments are generally more effective in solubilizing a greater fraction of lignin and opening up the crystalline cellulosic substrate. The alkali pretreatment is most widely used to enhance the enzymatic hydrolysis of the lignocellulose ${ }^{11}$. Alkali pretreatment processes utilize lower temperatures and pressures than other pretreatment technologies ${ }^{5}$. Compared with acid processes, alkaline processes cause less sugar degradation and many of the caustic salts can be recovered and/or regenerated. Sodium, potassium, calcium, and ammonium hydroxides are suitable alkaline pretreatment agents, where sodium hydroxide has been studied the most ${ }^{12}$. Dilute $\mathrm{NaOH}$ treatment of lignocellulosic materials has been found to cause swelling, leading to an increase in internal surface area, a decrease in polymerization degree and crystallinity of the cellulose, separation of structural linkages between lignin and carbohydrates, and disruption of the lignin structure ${ }^{12}$.

In the paper industry, the preferred method for delignification and obtention of cellulose from wood is the alkaline process denominated kraft. During the kraft process, most of the lignin and part of the hemicelluloses are extensively degraded and solubilized in the alkaline cooking liquor. The main active chemical agents in the kraft process are hydroxide and hydrosulfide anions which are present in the cooking liquor ${ }^{14}$. These agents cause a separation of the structural linkages between the lignin and carbohydrate and a disruption in the lignin structure, which in turn leads to an increase in the internal surface area and pore size. The hydrosulfide ion plays an important role in kraft pulping by accelerating delignification ${ }^{15}$. Chemicals and energy are recovered from black liquor by recovery boiler, which gives to the kraft process an advantage over other wood pretreatments.

Nevertheless, the kraft process has been found to be not economically competitive for ethanol production, unless some type of economic incentives or subsidies can be applied. According to Hytönen and Stuart, ${ }^{16}$ forestry companies are seeking improved profits from the implementation of new and sustainable business models, and one strategy could be exploiting the concept of biorefining. Zhu and Pan, ${ }^{17}$ indicate that the pulp and paper industries have the capability and infrastructure of handling biomass on the scale of 1000 ton/ day, equivalent to the scale of future cellulosic ethanol plants yielding in the order of 100 million liters/year. Consequently, they concluded that if ethanol production processes can use technologies, equipment and human capital in the pulp and paper industry, they will have a greater opportunity to success. An integrated forest biorefinery can provide to the paper and pulp industry a diversification in their products and even reduce pulp production $\operatorname{costs}^{16}$, which 
can involve the development of new strategies that add more value to the kraft process, such as the of use material not suitable for pulp fibber, including pulp sludge (solid and fines not suitable for pulp fibber), and forest residues for its conversion to bioethanol. Furthermore, since the conditions to be employed in the process to ethanol would be less severe, it would not be necessary to completely remove the lignin, thus reducing the cost of the kraft process. On the other hand, the kraft process for ethanol production can be used to reorient the usefulness of kraft mills. For example, in North America some kraft mills are being closed due to a decrease in the demand for paper, stimulating research projects in the field ${ }^{18}$.

The demand for alternative fuels is in great part due to government legislation and policies. Having a diversified energy matrix and energy security are crucial for developing countries and the global economy. In this regard, Chile is already taking action, with the National Fund for Scientific and Technological Development (FONDECYT) currently promoting research and development about using the kraft process for bioethanol production.

Then, a process traditionally used to produce pulp, can now be used to obtain ethanol. During pretreatment, the reactivity of cellulose for enzymatic hydrolysis can be sufficiently increased because kraft pulping removes most of the lignin and hemicelluloses originally in the wood. The aim of this research was to evaluate the use of the kraft process on E. globulus for bioethanol production by simultaneous saccharification and fermentation.

\section{EXPERIMENTAL}

\section{Kraft process}

Alkali pretreatment was performed by cooking industrial-size wood chips $(2.5 \times 1.5 \times 0.2 \mathrm{~cm})$ from $10-12$ years old E. globulus provided by a local pulp mill. The wood chips were thoroughly mixed to create a single uniform sample, and then air-dried and stored away in dry conditions before use. The samples were treated in a $1000-\mathrm{mL}$ Parr reactor loaded with $50 \mathrm{~g}$ of wood chips (dry basis) and a liquor-wood ratio of 5:1 (v/w) ${ }^{19}$. During this treatment the liquor composition was either $15 \%$ or $20 \%$ of active alkali (AA) and $25 \%$ of sulfidity (both calculated on a dry wood basis and expressed as $\mathrm{Na}_{2} \mathrm{O}$ equivalents). The reactor was heated at $1.6^{\circ} \mathrm{C} / \mathrm{min}$ and the experiments were performed at two different temperatures, $155^{\circ} \mathrm{C}$ and $165^{\circ} \mathrm{C}$, with treatment times of 15,30 and $60 \mathrm{~min}$. A total of 12 pulps were prepared as a result of the combination of the different pulping conditions used $(2 \mathrm{NaOH}$ concentrations $\mathrm{x} 2$ temperatures $\mathrm{x} 3$ cooking time). After cooking, pulps were disintegrated in a TAPPI laboratory blender, thoroughly washed with tap water, and centrifuged. Total pulp yield was determined based on the weight of the pulp divided by the weight of the wood chips (both on a dry basis) multiplied by 100 . After this, samples were stored in plastic bags at $4^{\circ} \mathrm{C}$.

\section{Chemical characterization of wood and pulp samples}

Milled wood samples (40/60 mesh) were extracted with ethanol/toluene according to the TAPPI method $204 \mathrm{~cm}-97$. Wood and pulp samples were characterized by their carbohydrate content using the methodology described by Ferraz et al. ${ }^{20} \mathrm{In}$ a test tube, $300 \mathrm{mg}$ of extractive-free milled wood was weighed and $3 \mathrm{~mL}$ of $72 \%(\mathrm{w} / \mathrm{w}) \mathrm{H}_{2} \mathrm{SO}_{4}$ was added. The hydrolysis was carried out in a water bath at $30^{\circ} \mathrm{C}$ for $1 \mathrm{~h}$ with stirring every $10 \mathrm{~min}$. Subsequently, the acid was diluted to $4 \%(\mathrm{w} / \mathrm{w})$ with $79 \mathrm{~mL}$ of distilled water and the mixture transferred to a $250-\mathrm{mL}$ Erlenmeyer flask and autoclaved for $1 \mathrm{~h}$ at $121^{\circ} \mathrm{C}$. The residual material was cooled, filtered through a number 4 sintered glass filter and washed with water. The solid fraction, which is insoluble lignin, was dried and weighed. The concentration of monomeric sugars in the soluble fraction was determined by high-performance liquid chromatography (HPLC) (Hewlett Packard 1050) equipped with a refractive index detector using a Aminex HTX-87H column (Bio-Rad, Hercules, CA, USA), at $45^{\circ} \mathrm{C}$, eluted at $0.6 \mathrm{~mL} /$ min with $5 \mathrm{mM} \mathrm{H} \mathrm{SO}_{4}$. Glucose and xylose were used as external calibration standards. The factors used to convert sugar monomers to anhydromonomers were 0.90 for glucose to glucan and 0.88 for xylose to xylan. All samples were analyzed in triplicate.

\section{Cellulose extraction from $E$. globulus kraft pulp}

The isolation of cellulose from kraft pulp was carried out according to the following procedure. One gram of sample was treated at $80^{\circ} \mathrm{C}$ for $25 \mathrm{~min}$ with a solution containing $40 \mathrm{ml}$ of water, $1.25 \mathrm{~g} \mathrm{NaClO}_{2}$ and $0.5 \mathrm{ml}$ acetic acid.
The insoluble residue (holocellulose $=$ celulosa + hemicellulose) was cooled, filtered through a number 2 sintered glass filter and washed with distilled water and acetone (Modified from Browning et al. ${ }^{21}$ ). The holocellulose was dried at $40^{\circ} \mathrm{C}$, weighed, and $0.5 \mathrm{~g}$ of this material was treated with $12.5 \mathrm{~mL}$ of $5 \%$ $\mathrm{KOH}$ at $20^{\circ} \mathrm{C}$ for $5 \mathrm{~min}$. Then, $12.5 \mathrm{ml}$ of water was added and treated for $5 \mathrm{~min}$ more at $20^{\circ} \mathrm{C}$. The resulting $\alpha$ cellulose was obtained filtered through a number 4 sintered glass filter and washed with distilled water and $1 \mathrm{M}$ acetic acid. It was dried at $40^{\circ} \mathrm{C}$ (Modified from Liu et al. ${ }^{22}$ ). In the case of $E$. globulus wood (control) was treated for $150 \mathrm{~min}$ for delignification and $35 \mathrm{~min}$ for extraction of cellulose.

\section{Crystallinity Measurements}

\section{X-Ray}

The isolated cellulose samples were pressed into pellets $(1.6 \mathrm{~cm}$ by $2.1 \mathrm{~cm}$ ) by compressing $0.2 \mathrm{~g}$ in a mold under a pressure of $5000 \mathrm{psi}$ for 45 s. Wide-angle X-ray diffraction profiles of the sample were obtained using a D4 ENDEAVOR X-ray diffractometer (Bruker, Germany). The diffraction patterns were recorded using $\mathrm{Cu}-\mathrm{K} \alpha$ radiation at $0.1542 \mathrm{~nm}, 40 \mathrm{kV}$ and $25 \mathrm{~mA}$. The diffracted intensity was measured in a $2 \theta$ range between $10^{\circ}$ and $40^{\circ}$ with a step size of 0.02 ; accumulation time for each step was $28.2 \mathrm{~s}$. The crystallinity index (CrI) was calculated as follows (Segal et al. ${ }^{23}$ ):

$$
C r I=\frac{I_{002}-I_{a m}}{I_{002}} \times 100
$$

Where $I_{002}=$ intensity of the diffraction from the 002 plane at about $2 \theta=$ 22.5 and $\operatorname{Iam}^{\mathrm{O}}=$ is the intensity of the baseline at about $2 \theta=18.4^{\circ}$, as shown in Fig.1

\section{Average degree of polymerization of cellulose}

The average degree of polymerization (DP) of isolated cellulose samples was calculated from its intrinsic viscosity $(\eta)$ using the equation: $\mathrm{DP}^{0: 90}=$ $1.65[\eta]$ proposed by Evans and Wallis ${ }^{24}$. The viscosity of the samples was measured according to TAPPI standard Method T230 om-04. The viscosity of a $0.5 \%$ cellulose solution in $0.5 \mathrm{M}$ cupriethylenediamine was measured on a capillary viscometer (Cannon Fenske Viscometer, Cannon Instrument Co., State College PA, USA)

Determination of enzymatic hydrolyzable carbohydrates in the pretreated material

The enzymatic hydrolysis was performed using a commercial preparation of Trichoderma reesei cellulases made of Celluclast $1.5 \mathrm{~L}(70 \mathrm{FPU} / \mathrm{mL}$; Novozymes, NC, USA), supplemented with B-glucosidase Novozym 188 (230 IU/mL; Novozymes, NC, USA). The amounts of enzyme were 20 FPU and $40 \mathrm{IU}$ per $\mathrm{g}$ of pretreated material. The enzymatic hydrolysis of the pretreated materials was carried out at $10 \%(\mathrm{w} / \mathrm{w})$ of consistency in $30 \mathrm{~mL}$ of a $0.05 \mathrm{M}$ solution of citrate buffer ( $\mathrm{pH} \mathrm{4.8)} \mathrm{solution,} \mathrm{in} \mathrm{a} \mathrm{shaker} \mathrm{at} 50^{\circ} \mathrm{C}$ and $150 \mathrm{rpm}$ for $96 \mathrm{~h}$. Samples were taken at 24, 48, 72 and $96 \mathrm{~h}$, and the content of glucose released was analyzed by HPLC. The yield was expressed as the percentage of glucose released in the enzymatic hydrolysis divided by the potential glucose in the pretreated material. All the determinations were performed in duplicate. Some samples were hydrolyzed using 10 FPU cellulases and 20 IU B-glucosidase per $\mathrm{g}$ of pretreated material.

\section{Simultaneous saccharification and fermentation (SSF)}

\section{Inoculum preparation}

The yeast strain utilized in this work was a thermal acclimatized $\left(40^{\circ} \mathrm{C}\right)$ Saccharomyces cerevisiae IR2T9 ${ }^{8}$. The inoculum was grown in $100 \mathrm{~mL}$ of liquid culture made out of glucose, $50 \mathrm{~g} / \mathrm{L}$; yeast extract, $5 \mathrm{~g} / \mathrm{L}$; peptone, 5 $\mathrm{g} / \mathrm{L} ; \mathrm{KH}_{2} \mathrm{PO}_{4}, 1.0 \mathrm{~g} / \mathrm{L} ; \mathrm{MgSO}_{4} \cdot 7 \mathrm{H}_{2} \mathrm{O}, 0.50 \mathrm{~g} / \mathrm{L} ; \mathrm{NH}_{4} \mathrm{Cl}, 2 \mathrm{~g} / \mathrm{L}$ in a $500 \mathrm{~mL}$ Erlenmeyer flask. The culture was incubated for $48 \mathrm{~h}$ at $40^{\circ} \mathrm{C}$ in an orbital shaker at $150 \mathrm{rpm}$.

The simultaneous saccharification and fermentation (SSF) was performed at $10 \%$ substrate consistency. In a $125 \mathrm{~mL}$ Erlenmeyer flask, the pretreated material with $70 \%$ humidity ( $3 \mathrm{~g}$ dry weight) was suspended in a total reaction 
volume of $30 \mathrm{~mL} 0.05 \mathrm{M}$ citrate buffer solution ( $\mathrm{pH} 4.8$ ). Nutrients, consisting in $\mathrm{KH}_{2} \mathrm{PO}_{4}, 1.0 \mathrm{~g} / \mathrm{L} ; \mathrm{MgSO}_{4} \cdot 7 \mathrm{H}_{2} \mathrm{O}, 0.50 \mathrm{~g} / \mathrm{L}$; peptone, $5.0 \mathrm{~g} / \mathrm{L}$; yeast extract, $5.0 \mathrm{~g} / \mathrm{L}$, were added. The SSF of the samples was performed using the same concentration and enzyme preparation used in enzymatic hydrolysis. After enzyme addition, the yeast inoculum was added at $6.0 \mathrm{~g} / \mathrm{L}\left(3.5 \times 10^{8}-3.3 \times 10^{9}\right.$ yeast cell $/ \mathrm{mL}$ ). SSF was performed at $40^{\circ} \mathrm{C}$ and $150 \mathrm{rpm}$ for $96 \mathrm{~h}$. Samples were taken at 24, 48, 72 and $96 \mathrm{~h}$ and analyzed for ethanol content by gas chromatography $(\mathrm{GC})$ on a Perkin-Elmer autosystem XL Headspace using a FID detector and a column HPS MS30m column. The GC program was: $50^{\circ} \mathrm{C} \times 3$ $\min ; 10^{\circ} \mathrm{C} / \mathrm{min}, 100^{\circ} \mathrm{C} \times 1 \mathrm{~min} ; 25^{\circ} \mathrm{C} / \mathrm{min}, 125^{\circ} \mathrm{C} \times 1 \mathrm{~min}$. The temperature of the injector and detector were 200 and $300^{\circ} \mathrm{C}$, respectively. Ethanol yields were calculated as a percentage of the theoretical yield. The theoretical yield was calculated by dividing the ethanol amount obtained (g) by the amount of glucose in pretreated material (g), assuming that all the potential glucose in the pretreated material is available for fermentation, with a fermentation yield of $0.51 \mathrm{~g}$ ethanol/g glucose multiplied by 100 . All the determinations were performed in duplicate.

\section{RESULTS AND DISCUSSION}

The chemical composition of the E. globulus used in this work was $45.6 \%$ glucan, $16.0 \%$ xylan, $26.3 \%$ lignin, $5.3 \%$ methylglucuronic acid and $1.2 \%$ ethanol/toluene-soluble extractives ${ }^{25}$. The isolated cellulose crystallinity from E. globulus wood was $77 \%$. Jahan and Mun ${ }^{26}$ reported similar cellulose crystallinity percentage (76\%) for Aspen and Nalita. The Pulp yields and chemical compositions of each pretreated material produced from E. globulus are shown in Table 1. The pulp yields ranged between 49 and $57 \%$. A total of 12 pulps were obtained under the different pretreatment conditions. The glucan and xylan content in the pulps ranged from 70 to $75 \%$ and 15 to $17 \%$, respectively. The glucan recovery in the solid fraction varied between $77 \%$ and $90 \%$, while almost $50 \%$ of the xylans were solubilized. Similar glucan recovery in the solid fraction using the organosolv process has been reported in the literature 27,28 .

Kraft pulping conditions were selected to employ shorter reaction times than those used for bleachable-grade pulp, obtaining a higher kappa number in some cases. Lignin content ranged from 1.4 to $10.5 \%$ which represents kappa number values from 10-42. Lignin removal increased with increasing alkali active loading, pretreatment time, and pretreatment temperature, leading to a delignification grade above $78 \%$ in the different pretreatments even with just 15 minutes of pretreatment. High residual lignin content in pulps can act as a barrier and / or as an inhibitor for the enzymes, making saccharification more difficult in the samples. Kraft pretreatment significantly removes lignin barriers allowing enzyme access. Therefore, the kraft process is effective as a pretreatment and can play a significant role in exposing the cellulose to enzyme hydrolysis. Even decreased severity of the pretreatment could result in pulps with higher yield and yet low lignin content.

Table 1. Chemical composition of pretreated E. globulus by kraft process.

\begin{tabular}{c|c|c|c|c|c|c|c|c|c|}
\hline Exp. No & $\begin{array}{c}\text { Tempe rature } \\
\left({ }^{\circ} \mathbf{C}\right)\end{array}$ & $\begin{array}{c}\text { AA } \\
(\%)\end{array}$ & $\begin{array}{c}\text { Time } \\
(\mathbf{m i n})\end{array}$ & $\begin{array}{c}\text { Pulp yie ld } \\
(\%)\end{array}$ & $\begin{array}{c}\text { Glucan } \\
(\%)\end{array}$ & $\begin{array}{c}\text { Hemicellulose } \\
(\%)\end{array}$ & $\begin{array}{c}\text { Lignin } \\
(\%)\end{array}$ & $\begin{array}{c}\text { Kappa } \\
\text { number }\end{array}$ & CrI (\%) \\
\hline A & 165 & 15 & 15 & 54 & 70 & 17 & 4.9 & 21 & 78 \\
B & & 15 & 30 & 54 & 70 & 16 & 3.2 & 15 & 77 \\
C & & 15 & 60 & 52 & 70 & 16 & 3.4 & 15 & 79 \\
D & & 20 & 15 & 49 & 72 & 15 & 2.4 & 16 & 80 \\
E & & 20 & 30 & 49 & 75 & 16 & 2.3 & 11 & 78 \\
F & & 20 & 60 & 49 & 73 & 16 & 1.4 & 10 & 81 \\
\hline G & 155 & 15 & 15 & 55 & 69 & 16 & 10.5 & 42 & 77 \\
H & & 15 & 30 & 57 & 72 & 17 & 7.1 & 33 & 77 \\
I & & 15 & 60 & 53 & 73 & 17 & 4.1 & 19 & 81 \\
J & & 20 & 15 & 56 & 71 & 15 & 8.4 & 33 & 80 \\
K & & 20 & 30 & 51 & 74 & 16 & 4.9 & 22 & 79 \\
L & & 20 & 60 & 50 & 70 & 15 & 2.8 & 17 & 80 \\
\hline
\end{tabular}

To determine, the crystalline degree of cellulose in the pulp obtained, $\mathrm{X}$-ray diffraction (XRD) was used. Figure 1 shows an example of the X-ray diffractogram of a kraft pulp. Cellulose crystallinity increases with AA charge during kraft pretreatment. Values ranged between 77 and $81 \%$, which represent a slightly increase between 1 and $5 \%$. The increase of crystallinity can be related to the solubilization of lignin and amorphous cellulose degradation in the pretreatment.

Evans et al. ${ }^{29}$ observed an increase in the cellulose CrI as kraft pulping proceeded due to preferential removal of the less ordered carbohydrates. A similar result was reported in other alkaline pretreatment (lime) where the CrI increased slightly ${ }^{30}$.

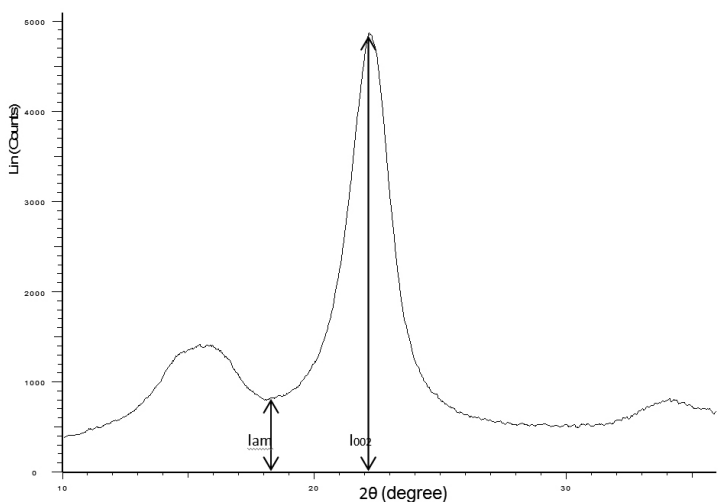

Figure 1. X-ray diffractogram of an E. globulus kraft pulp.

\section{Enzymatic hydrolysable carbohydrates in the pretreated material}

The E. globulus pulp digestibility was evaluated by enzymatic hydrolysis. Figure 2 shows the enzymatic hydrolysis of samples for four hydrolysis periods $(24,48,72$ and $96 \mathrm{~h})$. All pulps obtained present a rapid conversion of glucan to glucose, reaching conversion values between 86 and $100 \%$, probably due to new structural features of the pretreated material, thus facilitating enzyme accessibility. The saccharification yields are just slightly higher for the pulps pretreated at $165^{\circ} \mathrm{C}$ than those pretreated at $155^{\circ} \mathrm{C}$, for both AA concentrations (Table 2). Cellulose enzymatic hydrolysis is a complex process and a structural characteristic may not by itself adequately explain differences in the hydrolysis ${ }^{29}$. Digestibility of lignocellulosic biomass is affected by the structural properties of cell-wall components such as lignin/hemicellulose association, cellulose crystallinity index CrI and polymerization degree DP 5 , $30,32-34$.

The results indicate that all the kraft pretreatment conditions employed in this study effectively improve the enzymatic digestibility of material. Even though the crystallinity is high, the amount of adsorbed enzyme is sufficient to achieve high digestibility. This must be due in part to the decreasing number of non-specific binding sites on lignin, making more enzymes available for hydrolysis. Similar effects have been reported by Kim and Holtzapple ${ }^{34}$. Even under lower severity condition as $155^{\circ} \mathrm{C}, 15 \% \mathrm{AA}$, the pulp obtained, with $11 \%$ lignin content (42 kappa number), presented $93 \%$ enzymatic hydrolysis. This indicates that it is not necessary to remove all lignin to render the biomass digestible, so a pulp with 42 kappa number can be efficiently hydrolyzed. According to Chang and Holtzapple, ${ }^{30}$ only $43 \%$ lignin removal is needed for it to become highly digestible ( $80 \%)$. In addition, a $50 \%$ of hemicellulose removal may have some effect in the increase of the enzymatic hydrolysis yield. Hemicellulose affects the enzymatic hydrolysis, since it forms a physical barrier 
to enzyme attack by covering the cellulose microfibrils in the cell wall ${ }^{30}$. Since DP is other characteristic related with enzymatic hydrolysis yield, cellulose $\mathrm{DP}$ was determined for $\mathrm{B}$ and $\mathrm{H}$ samples, which showed the highest $(100 \%)$ and lowest $(86 \%)$ enzymatic hydrolysis, respectively. The B and $\mathrm{H}$ samples presented DP values of 3056 and 4583 units, respectively. This indicates that DP has an effect on enzymatic hydrolysis of the kraft pulps; shorter chains allow cellulose to be more amenable to enzymatic deconstruction since they form weaker networks fostering enzyme access ${ }^{35-37}$. On the other hand, the slight increase of CrI seems have no effect on enzymatic hydrolysis. Chang and Holtzapple ${ }^{30}$, have reported that crystallinity can affect the efficiency of the enzyme in contact with cellulose, its more significant effects being on the initial hydrolysis rates instead of the ultimate sugar yields (at $72 \mathrm{~h}$ ), indicating that $\mathrm{CrI}$ is responsible for the effectiveness of enzymes adsorbed on the substrate. Low lignin content is sufficient to obtain high digestibility regardless of CrI; equally a low CrI is sufficient regardless of lignin ${ }^{30}$.
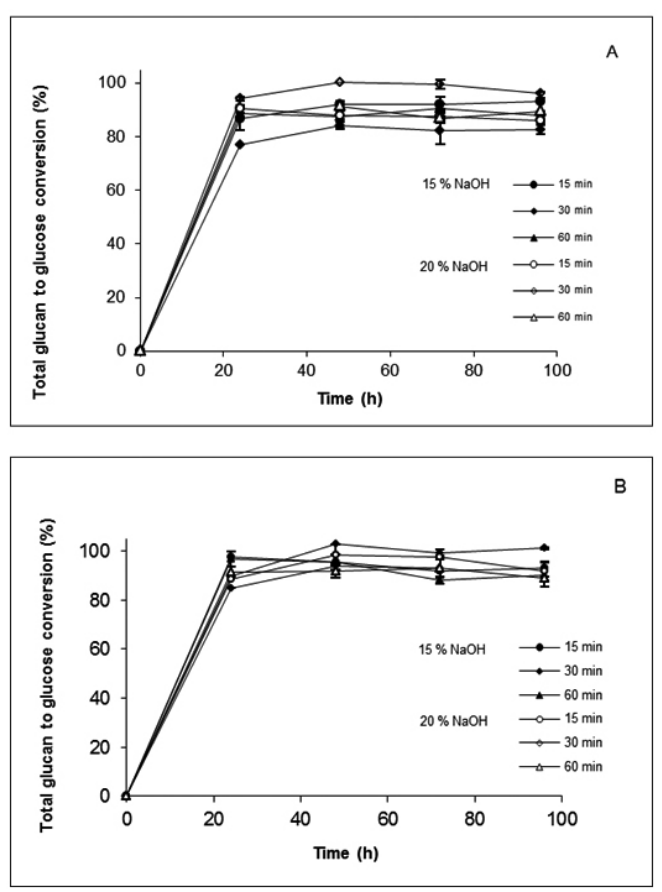

Figure 2 Enzymatic hydrolysis of glucan contained in E. globulus kraft pulps. $155^{\circ} \mathrm{C}(\mathrm{A})$ and $165^{\circ} \mathrm{C}(\mathrm{B})$.
To evaluate the possible reduction of enzymatic loading, B and $\mathrm{H}$ samples were subjected to an enzymatic hydrolysis with 10 FPUcellulase and 20 IU B-glucosidase per $\mathrm{g}$ of pretreated material using the same consistency. B and $\mathrm{H}$ samples performed $96 \%$ and $82 \%$ enzymatic hydrolysis, respectively. These results were similar to enzymatic hydrolysis carried out with 20 FPU cellulasa and 40 IU B-glucosidase, with a greater enzyme load being unnecessary.

The enzymatic hydrolysis yields obtained are comparable to the amount reported by Emmel et al. ${ }^{38}$ and Parajó et al. ${ }^{39}$ for E. grandis and E. globulus, respectively. Emmel et al. ${ }^{38}$ achieved a maximal glucan conversion close to $89 \%$, with a dilute acid catalyzed steam explosion $\left(200^{\circ} \mathrm{C}, 2 \mathrm{~min}\right.$ and $0.087 \%$ acid). Parajó et al. ${ }^{39}$ achieved a maximal glucan conversion close to $92 \%$; they employed two pretreatment stages, the first was with acid catalyzed organosolv $\left(118^{\circ} \mathrm{C}, 60 \mathrm{~min}\right)$ and the second was $\mathrm{NH}_{3 \text { (ac) }}\left(60^{\circ} \mathrm{C}, 180 \mathrm{~min}\right)$. Recently, $\mathrm{Yu}$ et al. ${ }^{2}$ achieved $81.5 \%$ enzymatic hydrolysis after a two-step liquid hot water (TSLHW) pretreatment of E. grandis at $180{ }^{\circ} \mathrm{C}$ for $20 \mathrm{~min}$ and at $200{ }^{\circ} \mathrm{C}$ for $20 \mathrm{~min}$. Another alkaline pretreatment similar to the kraft paper pulping technology, ${ }^{40}$ obtained $77 \%$ of enzymatic hydrolysis from poplar wood pretreated with oxidative lime (calcium hydroxide with oxygen) at $150^{\circ}$ for $360 \mathrm{~min}$.

These results indicate that the kraft process increases cellulose reactivity for enzymatic hydrolysis.

\section{Simultaneous saccharification and fermentation (SSF)}

The ethanol yields obtained from kraft pulps varied between 86 and $100 \%$ (pulp basis) and 65 and $78 \%$ (wood basis). The maximum ethanol yields were $78 \%$ at $155^{\circ} \mathrm{C}, 15 \% \mathrm{AA}$ and $60 \mathrm{~min}$ reaction; and $74 \%$ at $165^{\circ} \mathrm{C}, 15 \% \mathrm{AA}$ and a $30 \mathrm{~min}$ reaction was $74 \%$ (Table 2 ). The amounts of ethanol obtained ranged between 168 and $202 \mathrm{~g}$ ethanol $/ \mathrm{kg}$ wood (Table 2).

The major effect of the kraft pretreatment is removal of lignin and hemicellulose from the biomass, thus improving the reactivity of the cellulose. Compared to other pretreatment technology, such as acid and/ or organosolv processes ${ }^{12,41}$, the kraft pretreatment presents less sugar degradation, removes most of the lignin, it is performed at lower temperature and pressure, and the caustic salts can be recovered and/ or regenerated. In addition, kraft pulps require lower amounts of enzyme to carry out an efficient enzymatic hydrolysis.

To obtain high yields of ethanol from kraft pulps by SFS process required the use of a thermotolerant yeast strain (Saccharomyces cereviseae IR2 -9a). This strain was adapted to grow and produce ethanol in SFS process at $40^{\circ} \mathrm{C}^{42}$. Thus, it is possible to convert kraft pulp into ethanol at temperatures closer to the optimal for enzymatic hydrolysis making the SSF more efficient ${ }^{42}$.

Table 2. Saccharification and bioethanol conversion of E. globulus (pulp and wood basis).

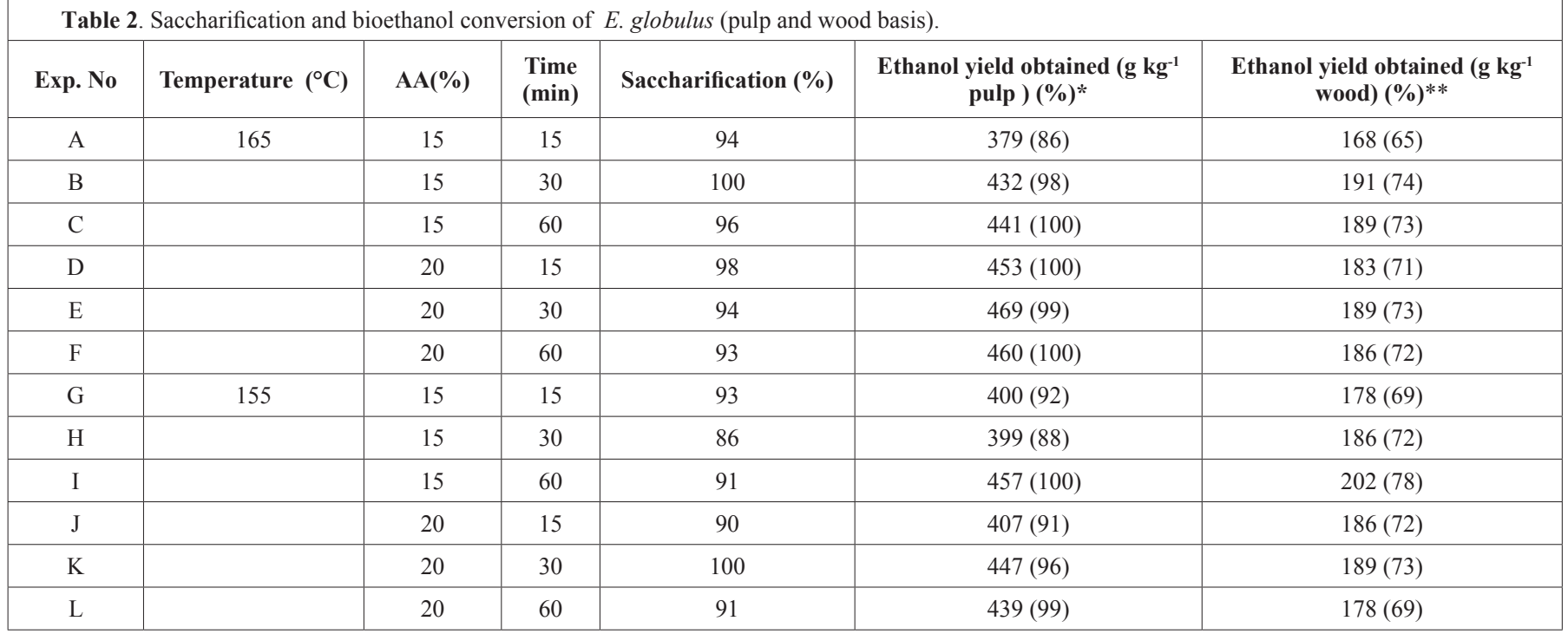

* Percent ethanol on pulp basis, ** Percent ethanol on wood basis 
Nevertheless, the production and capital investment costs are the factors that determine the kraft process profitability in regards to ethanol production. For this reason, one valid option is to integrate the biorefineries in the pulp and paper industry. The demands for a non-fossil carbon economy and new concepts in the pulp and paper industry create the opportunity for this new platform, which involves developing new strategies that add more value to the kraft process, through the use of hemicellulose, pulp sludge such as solid and fines not suitable for pulp fibber, and forest residues for its conversion to ethanol. Also, our research indicates that lower severity conditions and enzymatic loading could be used, which contributes to reduce production cost. This idea is influenced by energy security, greenhouse gases mitigation, and a reduction of forest residues and associated policy measures.

\section{CONCLUSIONS}

Our results indicate that the kraft process is a very effective pretreatment that significantly reduces lignin content and increased cellulose reactivity for enzymatic hydrolysis, regardless of crystallinity. Consequently, it can be used in the ethanol production processes with excellent results. Besides, it offers unique opportunity to convert the pulp and paper industry into integrated biorefineries that can efficiently use and optimize all affordable lignocellulosic waste sources adding more value to the overall strategy. Indeed, biofuels production is particularly attractive option to improve the profitability of the pulp and paper industry.

\section{ACKNOWLEDGEMENTS}

Financial support was received from SENACYT and FONDECYT (grant 3100043 and 1110819).

\section{REFERENCES}

1. Y. Zheng, Z. Pan, R. Zhang, and D. Wang, Applied Energy 86, 2459 (2009).

2. Q. Yu, X. Zhuang, Z. Yuan, Q. Wang, W. Qi, W. Wang, Y. Zhang, J. Xu, and H. Xu, Bioresour. Technol. 101, 4895 (2010).

3. M. Himmel, S. Ding, D. Johnson, W. Adney, M. Nimlos, J. Brady, and T. Foust, Science 315, 804 (2007).

4. B. Um, M. Karim, and L. Henk, Appl. Biochem. Biotechnol. 105, 115 (2003).

5. N. Mosier, C. Wyman, B. Dale, R. Elander, Y. Lee, M. Holtzapple, and M. Ladisch, Bioresour. Technol. 96, 673 (2005).

6. J. Kristensen, L. Thygesen, C. Felby, H. Jorgensen, and T. Elder, Biotechnology for Biofuels 1, 1 (2008).

7. L. Zhu, J. O'Dwyer, V. Chang, C. Granda, and M. Holtzapple, Bioresour. Technol. 99, 3817 (2008).

8. E. Araque, C. Parra, J. Freer, D. Contreras, J. Rodríguez, R. Mendonça, and J. Baeza, Enzym. Microb. Tech. 43, 214 (2008).

9. I. Ballesteros, M. Negro, J. Oliva, A. Cabanas, P. Manzanares, and M. Ballesteros, Appl. Biochem. Biotechnol. 130, 496 (2006).

10. C. Muñoz, R. Mendonça, J. Baeza, A. Berlin, J. Saddler, and J. Freer, J. Chem. Tech. Biotechnol. 82, 767 (2007).

11. R. Laxman and A. Lachke, In: Ashok Pandey, editor. Handbook of PlantBased Biofuels,Boca Raton:Taylor \& Francis Group, 121 (2009).

12. P. Kumar, D. Barrett, M. Delwiche, and P. Stroeve, Ind. Eng. Chem. Res. 48, 3713 (2009).

13. L. Ramos, Quím. Nova 26, 863 (2003).

14. E. Sjöström, Wood chemistry. Fundamentals and applications, 2nd ed. London, UK: Academic Press Inc., 1993.

15. H. Sixta, A. Potthast, and A. Krotschek, Handbook of Pulp, Herbert Sixta ,Ed., WILEY-VCH Verlag GmbH \&Co. KGaA, Weinheim, 109 (2006).

16. E. Hytönen and P. R. Stuart, Pulp \& Paper Canada 110, 25 ( 2009).

17. J. Y. Zhu and X. J. Pan, Bioresour. Tech. 101, 4992 (2010).

18. Y. Jin, H. Jameel, H.-m. Chang, and R. Phillips, J. Wood Chem. Tech. 30, $86(2010)$.

19. M. Monrroy, L. Sanhueza, R. Teixeira Mendonca, J. Baeza, and J. Freer, J. Chil. Chem. Soc. 54, 238 (2009).

20. A. Ferraz, J. Baeza, J. Rodriguez, and J. Freer, Bioresour. Technol. 74, 201 (2000).

21. B. Browning, Methods of wood chemistry. Wiley Interscience Publishers, New York, USA, 1967.

22. R. G. Liu, H. Yu, and Y. Huang, Cellulose 12, 25 (2005).

23. L. Segal, J. J. Creely, A. E. Martin, Jr., and C. M. Conrad, Textile Research
Journal 29, 786 (1959).

24. R. Evans and A. F. A. Wallis, J. Appl. Polym. Sci. 37, 2331 ( 1989).

25. M. Monrroy, R. Mendonça, J. Rodríguez, J. Baeza, and J. Freer, Appita J. 61, 212 (2008).

26. M. Jahan and S. Mun, Wood Sci. Tech. 39, 367 (2005).

27. X. Pan, N. Gilkes, J. Kadla, K. Pye, S. Saka, D. Gregg, K. Ehara, D. Xie, D. Lam, and J. Saddler, Biotech. Bioeng. 94, 851 (2006).

28. P. Sannigrahi, S. J. Miller, and A. J. Ragauskas, Carbohydr. Res. 345, 965 (2010).

29. R. Evans, R. H. Newman, and U. C. Roick, Holzforschung 49, 498 (1995).

30. V. Chang and M. Holtzapple, Appl. Biochem. Biotechnol 84, 5 (2000).

31. S. Park, J. Baker, M. Himmel, P. Parilla, and D. Johnson, Biotechnology for Biofuels 3, 10 (2010)

32. M. Yoshida, Y. Liu, S. Uchida, K. Kawarada, Y. Ukagami, H. Ichinose, S. Kaneko, and K. Fukuda, Biosci. Biotech. Biochem. 72, 805 (2008).

33. V. Arantes and J. Saddler, Biotechnology for Biofuels 3, 4 (2010).

34. S. Kim and M. Holtzapple, Bioresour. Technol. 97, 583 (2006).

35. X. Pan, D. Xie, R. W. Yu, and J. N. Saddler, Biotech.Bioeng. 101, 39 (2008).

36. V. P. Puri, Biotech.Bioeng. 26, 1219 (1984).

37. B. B. Hallac, P. Sannigrahi, Y. Pu, M. Ray, R. J. Murphy, and A. J. Ragauskas, Ind. Eng. Chem. Res. 49, 1467 (2010).

38. A. Emmel, A. Mathias, F. Wypych, and L. Ramos, Bioresour. Technol. 86, 105 (2003).

39. J. Parajó, J. Alonso, and V. Santos, Proc. Biochem. 30, 537 (1995).

40. V. Chang, M. Nagwani, C. Kim, and M. Holtzapple, Appl. Biochem. Biotechnol. 94, 1 (2001).

41. F. Carrillo, M. Lis, X. Colom, M. López-Mesas, and J. Valldeperas, Proc. Biochem. 40, 3360 (2005)

42. E. Araque, C. Parra, J. Freer, D. Contreras, J. Rodriguez, R. Mendonca, J. Baeza, Enzyme Microb. Technol 43, 214 (2008). 